\title{
Study on Practical Education System of Local Colleges Innovation and Entrepreneurship under New Situation
}

\author{
Wei Qin, Xi Chen
}

Xi'an University, Xi'an, Shaanxi, 710065

\author{
Keywords: Practical Education System, Local Colleges, New Situation
}

\begin{abstract}
Entrepreneurship Education in the New Situation Has Become an Inevitable Trend of Higher Education Reform. As the main part of higher education system in our country, carrying out innovation and entrepreneurship education is an effective way for local colleges to enhance the core competitiveness of running schools, improve the quality of personnel training and achieve sustainable development. In view of the existing problems of local colleges in the concept of entrepreneurship education, curriculum system, faculty, etc., put forward reform measures.
\end{abstract}

\section{Introduction}

In the popularization of higher education in our country, local colleges are the main force to realize the transition from elitism to popularization of higher education in our country, and play an important role in giving full play to the social service function of higher education. However, due to various subjective and objective reasons, local university graduates are obviously disadvantaged in employment competition with graduates of key institutions due to the lack of "brand name effect." The employment situation of local college graduates is becoming more and more severe. Relieving the employment pressure of graduates with traditional employment mode can not meet the increasing army of graduates. Multi-channel employment, especially self-employment, has alleviated the employment pressure of current graduates The main channel. Local colleges to carry out entrepreneurship education oriented to the needs of regional economic development and to cultivate innovative and entrepreneurial talents are not only an effective way to improve the core competitiveness of school running, expand students' sources and achieve sustainable development, but also serve as a platform for local colleges to serve local regional economic development and adapt to national industries The necessary requirements of structural adjustment.

\section{Local colleges innovation and entrepreneurship education status quo}

Has not formed a systematic innovation and entrepreneurship education curriculum system. Innovation and entrepreneurship education as an important part of personnel training, its academic status no doubt. In western countries, entrepreneurship education in universities has a long history, and the curriculum system of entrepreneurship education is relatively systematic. Most colleges in our country have not yet started entrepreneurship education. Even though some colleges have carried out pilot projects, the entrepreneurship education courses offered are still fragmented and are not integrated into the disciplinary education system, most of which are only used as elective courses or entrepreneurship education after school hours, There is no system of entrepreneurial education curriculum system, it is difficult to comprehensively improve the quality of entrepreneurship.

It is well-known that human creativity can not be imparted like concrete knowledge and skills. It can only be nurtured and enlightenment nurtured and engendered through the pioneering and innovative spirit implied by specific knowledge and skills. Therefore, entrepreneurial education must not be carried out in isolation from professional education. Lack of teachers with innovative entrepreneurial awareness and entrepreneurial practice. Teaching staff is the decisive factor that determines the quality of innovation and entrepreneurship education. At present most of the teachers are still very conservative in their educational concepts. They think that as long as students master 
their professional knowledge and skills and graduate smoothly, they can seek a good position in the society and do not advocate that college students start their own businesses. They even think it is not to learn No performance. Of course, this will be affected to some extent by the atmosphere of employment-oriented personnel training in schools, but the most important reason lies in the quality of teachers. For example, most teachers lack entrepreneurial skills, entrepreneurial knowledge and entrepreneurship. At present, the teachers who carry out entrepreneurship education courses in colleges mainly come from the teachers who engaged in the teaching of economics and management, the students' employment guidance teachers and counselors. Most of these teachers lack practical experience in starting a business, and they still stay on the stage of pioneering education, In theory teaching, lack of experience to teach, can not really cultivate students' entrepreneurial awareness and entrepreneurial ability. Universities generally lack of both exquisite professional theoretical knowledge, but also rich practical experience in industry enterprises, "Double Teachers" team. Lack of specialized entrepreneurial education organizations. Organizational management of entrepreneurial education is the organizational guarantee for carrying out various teaching activities in innovation and pioneering education. Setting up a special entrepreneurial education management institution and giving full play to its management efficiency are the prerequisites for carrying out innovation and pioneering education. Many colleges management of entrepreneurial education is still relatively dispersed, have not formed a systematic management model. In the organizational structure, many colleges only set up entrepreneurial leading group; in the implementation of entrepreneurship education, most colleges by the Communist Youth League, students, employment guidance center and other departments as a way to promote the employment of college students to organize and implement, not included in the school routine teaching management Links. Admittedly, the multisectoral management of entrepreneurial education together can effectively promote the development of entrepreneurship education. However, the management of entrepreneurship education in a number of parallel departments will result in ambiguous division of labor and confusion in management, which can not effectively and smoothly carry out the education for entrepreneurship. This decentralized management model of entrepreneurship education is hardly able to achieve the desired teaching effect.

\section{Local colleges innovation and entrepreneurship education path}

Establish a comprehensive innovation and entrepreneurship education concept. For a long time, colleges in our country have paid great attention to the training of knowledgeable and passive employment-oriented talents. They attach importance to the study and mastery of theoretical and technical skills, neglect the cultivation of active entrepreneurial talents, neglect the cultivation of college students' innovative awareness and entrepreneurial ability, , Mental health and other comprehensive quality of education, so that trained students stick to conventions, eyeing low, do not know how to deal with interpersonal problems and other issues in the community more difficult to employers welcome. Therefore, only by establishing a comprehensive concept of entrepreneurship education can schools, societies and students profoundly understand the importance of entrepreneurship education ideologically so as to support and carry out entrepreneurial education in their actions. The school should change the training of knowledge-based talents to the cultivation of a comprehensive quality-oriented talent with knowledge, skills and creativity, and constantly strengthen the cultivation of university students' entrepreneurial awareness and entrepreneurial skills. To "educate people" as the core, people-oriented, give full play to the individual potential of students, focus on improving the overall quality of college students, and promote the all-round development of college students. The innovation and entrepreneurship education throughout the entire process of teaching, management, service, all students to carry out innovation and entrepreneurship education, innovation and entrepreneurship education as a platform to further deepen the quality of education, improve students' awareness of innovation and entrepreneurial ability and enhance the overall quality of students . Construct Curriculum System Based on Innovation and Entrepreneurship. Entrepreneurship is a complex process. Establishing a curriculum system with entrepreneurial 
education features is a prerequisite for effectively launching entrepreneurship education. Therefore, starting a business education program should include courses on entrepreneurship, business communication and exchange, marketing, financing and business opportunities. A series of supporting courses, such as law, management and psychology, which are closely related to the start-up, build a systematic innovation and entrepreneurship education curriculum system and fully cultivate high-quality innovative entrepreneurship talents. Strengthen the construction of teaching staff in entrepreneurship education. Actively employ teachers with entrepreneurial experience outside the school, hired from outside the school a group of entrepreneurial experience, know how business management talent or business, taxation, banking and other economic management functions of excellent staff as entrepreneurship education part-time teachers to teach classes or Lecture. These part-time teachers are the elites of the society. Therefore, they can stimulate their passion for innovation and entrepreneurship and enable them to learn first-hand practical experience of entrepreneurship directly from them, so as to greatly enhance the teaching effect of entrepreneurship education. Improve the professionalism of full-time teachers in entrepreneurship education, entrepreneurship education is not only teaching entrepreneurial theory knowledge, more importantly, teaching entrepreneurial practical experience. The establishment of a business incentive mechanism to encourage full-time teachers to participate in business management activities such as research, support for full-time teachers with entrepreneurial practice in entrepreneurship, access to entrepreneurial first-hand experience; to strengthen the entrepreneurship education and training of full-time teachers to improve their teaching of entrepreneurship education Ability; organize teachers to participate in entrepreneurial education-related academic exchange, learn and learn from other advanced entrepreneurial education experience. Enhance the teachers' sense of innovation and entrepreneurship, change the traditional knowledge-based classroom teaching, and establish an innovative people-centered classroom teaching.

Reform, innovation and entrepreneurship education management. All colleges should combine their own actual conditions, the entrepreneurial education management into the routine teaching management part of the school, set up a special entrepreneurial education organizations, and establish a sound entrepreneurial education management. Establish a university entrepreneurship center that can absorb undergraduates for scientific and technological innovation and entrepreneurship design activities [2]. Deepen teaching management and student management. In the aspect of teaching management, reform and improve the flexibility of credit system to create an atmosphere of innovation and entrepreneurship conducive to the all-round development of students. Students who possess the entrepreneurial abilities and entrepreneurial conditions may retain their school records and encourage them to go out to start their own businesses. . In student management, establish a sound incentive mechanism to encourage students to actively participate in innovation and entrepreneurship training, to stimulate the entrepreneurial enthusiasm of college students, to cultivate college students entrepreneurial awareness and entrepreneurial capacity.

\section{Conclusion}

Deepen the innovation and pioneering education and teaching reform. Entrepreneurship education is not only in teaching content, but also in teaching methods and traditional employment education are very different. In the classroom teaching method, in addition to traditional knowledge teaching, entrepreneurial education should adopt participatory methods such as discussion, case study and entrepreneurs' discussion to make students more intuitively understand entrepreneurial entrepreneurship, entrepreneurial ability and entrepreneurial process of successful entrepreneurs. In extracurricular activities, entrepreneurship education is carried out in a variety of forms such as entrepreneurship planning competitions and entrepreneurial education lectures [2]. Outside the school, schools should further strengthen the cooperation between schools and enterprises, jointly establish an innovation and entrepreneurship education practice base, and build a practical platform for the students' innovation and entrepreneurship activities. In addition, but also to create a pioneering teaching style of study. 


\section{Acknowledgements}

Fund Project: The Year of 2017 for Education Science in Shaanxi Province in the 13th Five-Year Plan (SGH17H221): A Study on the Practical Education System of Innovation and Entrepreneurship in Local Universities under the New Situation

\section{References}

[1] Caosheng Li. Building an innovative country and training innovative entrepreneurs - on the "Third Education Pass" several recognition issues [J]. China Higher Education Research. 2008 (05)

[2] WU Ze-jun. Innovation and entrepreneurship education in colleges and its implications [J]. Nanchang Institute of Technology. 2007 (05)

[3] Gao Xiaojie, Cao Shengli. Innovation and entrepreneurship education - a pioneer in cultivating a new era of the cause - Summary of the China Higher Education Association Innovation and Entrepreneurship Education Symposium [J]. China Higher Education Research. 2007 (07)

[4] Chen Haokai, Xu Ping Lei. India and the United States compared the pattern of entrepreneurship education and China's entrepreneurship education [J]. China Higher Education Research. 2006 (09)

[5] Housing want to fly. University entrepreneurship education in the UK [J]. Shanghai Education. 2006 (12)

[6] Zhang Dejiang. Knowledge and practice of entrepreneurship education [J]. China Higher Education Research. 2006 (05)

[7] Luo Mei-ping. China's college students entrepreneurship education status quo and Countermeasures [J]. Zhejiang Gongshang University, 2006 (02) 